Macmillan Business Masters

\title{
Personnel Management
}

Third Edition 


\section{Macmillan Business Masters}

Company Accounts (3rd edn) Roger Oldcorn

Economics S. F. Goodman

Financial Management (3rd edn) Geoffrey Knott

Management (3rd edn) Roger Oldcorn

Marketing Geoff Lancaster and Paul Reynolds

Operations Management (2nd edn) Howard Barnett

Personnel Management (3rd edn) Margaret Attwood and Stuart Dimmock 


\section{Personnel \\ Management}

\section{Third Edition}

Margaret Attwood

and

Stuart Dimmock

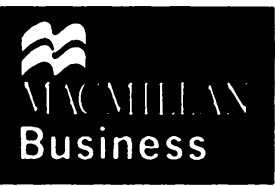


(c) Margaret Attwood 1985, 1989

(C) Margaret Attwood and Stuart Dimmock 1996

All rights reserved. No reproduction, copy or transmission of this publication may be made without written permission.

No paragraph of this publication may be reproduced, copied or transmitted save with written permission or in accordance with the provisions of the Copyright, Design and Patents Act 1988, or under the terms of any licence permitting limited copying issued by the Copyright Licensing Agency, 90 Tottenham Court Road, London WIP 9HE.

Any person who does any unauthorised act in relation to this publication may be liable to criminal prosecution and civil claims for damages.

First published by Pan Books Ltd as Introduction to Personnel Management in the Breakthrough series in 1985

Published by Macmillan 1989

MACMILLAN PRESS LTD

Houndmills, Basingstoke, Hampshire RG21 6XS

and London

Companies and representatives

throughout the world

ISBN 978-0-333-65006-6 ISBN 978-1-349-13939-2 (eBook)

DOI 10.1007/978-1-349-13939-2

A catalogue record for this book is available from the British Library.

This book is printed on paper suitable for recycling and made from fully managed and sustained forest sources.

$\begin{array}{llllllll}11 & 10 & 9 & 8 & 7 & 6 & 5 & 4\end{array}$

$\begin{array}{llllll}06 & 05 & 04 & 03 & 02 & 01\end{array}$

Typeset in Great Britain by

Aarontype Limited

Easton, Bristol 
To Bill, Abi and Jonathon 


\section{Contents}

1 Definitions of Personnel Management 1

1.1 The Structure and Organisation of a Personnel Department

1.2 Who Practises Personnel Management? 5

1.3 Personnel Roles and Responsibilities 5

1.4 Universal Good Practice in Personnel Management:

A Myth for Students or a Reality for Practitioners? 7

1.5 Is Personnel Management a Profession? 8

2 Planning for People in Organisations 10

2.1 What is Human Resource Planning? 10

2.2 Stage 1: Analysis of Current Staff in the Organisation and Past Trends

2.3 Stage 2: Analysis of the Organisation's Future Plans in Human Resource Terms

2.4 Stage 3: Analysis of the Matches or Mismatches between Human Resource Supply and Demand Forecasts 23

2.5 Stage 4: Evaluating the Options 24

2.6 Stage 5: Selection of Best Alternatives and Implementation as the Human Resource Plan, with Monitoring and Review Procedures

3 Recruitment and Selection $\quad 28$

3.1 How to Start 28

3.2 Stage 1: Defining the Job to be Done 29

3.3 Stage 2: Defining the Ideal Candidate 33

3.4 Stage 3: Attracting Candidates 35

3.5 Stage 4: Selecting Candidates 38

3.6 The Follow-Up Process 49

3.7 Managerial Roles in Recruitment and Selection 50 
4 Introducing the Individual to the Organisation 51

4.1 What is Induction? 51

4.2 The Induction Process $\quad 52$

4.3 Induction for Senior Staff $\quad 54$

4.4 Induction Training $\quad 54$

4.5 Roles in Induction $\quad 56$

4.6 A Final Word $\quad 56$

5 The Law and the Rights of the New Employee 59

5.1 The Legal Framework of Employees' Rights 59

5.2 The Law and the Rights of Job Applicants 60

$\begin{array}{ll}5.3 & \text { What is Discrimination? } \\ 5.4\end{array}$

5.4 Coverage of the Anti-Discrimination Legislation 64

5.5 The Contract of Employment 66

5.6 Summary: Case Study $\quad 69$

6 Involving the Individual in the Job 72

$\begin{array}{lll}6.1 \text { Motivation } & 72\end{array}$

$\begin{array}{ll}6.2 \text { Orientations to Work } & 75\end{array}$

6.3 Designing Jobs to Encourage Efficiency and Commitment 76

6.4 Direct Participation as a Means of Encouraging Employee Commitment $\quad 79$

7 Appraising Performance $\quad 85$

7.1 What is Performance Appraisal?

7.2 Purpose of Performance Appraisal $\quad 85$

7.3 Designing an Appraisal System $\quad 86$

$\begin{array}{lll}7.4 & \text { Performance-Related Pay } & 91\end{array}$

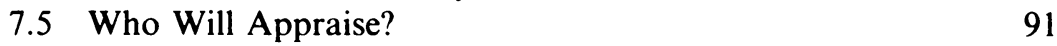

$\begin{array}{lll}\text { 7.6 The Appraisal Interview } & 91\end{array}$

7.7 Training for Appraisal 92

7.8 Other Problems of Appraisal 92

7.9 Conditions Necessary for Successful Appraisal Schemes 93

8 Training for Current Jobs 96

8.1 What is Training? 96

8.2 Objectives of Training 97

$\begin{array}{lll}8.3 & \text { Training Policy } & 97\end{array}$

8.4 A Systematic Approach to Training 98

8.5 Stage 1: The Identification of Training Needs 98

8.6 Stage 2: The Planning of Training Programmes 103

8.7 Stage 3: Implementing Training Programmes 110

8.8 Stage 4: The Evaluation of Training Programmes 111

8.9 Role of the Training Specialist 113 
9 Developing Organisations for the Future 114

9.1 Organisation Development 114

9.2 Where Should Organisation Development Take Place? 116

9.3 The Role of Personnel Specialists in Organisation Development 117

9.4 Organisation Development Tools and Techniques 117

9.5 Changing Our Pictures of Effective Organisations 118

9.6 The Essence of Learning Cultures for Developing

10 Developing People for the Future 122

10.1 What is Development? 122

10.2 What is Good Development? 123

10.3 Management Development 123

10.4 The Focus of Management Development 125

10.5 A Systematic Approach to Management Development 125

10.6 Managerial Succession Planning 127

10.7 Analysis of Development Needs 128

10.8 Selecting for Management Development 128

10.9 Other Ways of Creating Individual Development Plans 130

10.10 Designing Management Development Programmes 130

10.11 Evaluation of Management Development 136

10.12 Career Development for Young People 136

10.13 Equal Opportunities in Career Development 138

10.14 Development of High Flyers 139

10.15 A Final Word on Development 139

11 Looking after Employees: Welfare and

Counselling Services

11.1 How Can we Define 'Welfare' in the Context of
Modern Personnel Management?

11.2 Occupational Stress 143

11.3 Personal Services for Employees: Counselling 143

11.4 Group Services for Employees 146

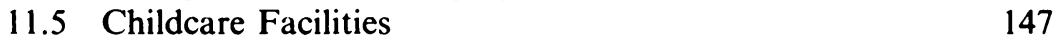

11.6 Status Considerations 148

11.7 The Future of Employee Services 148

12 The Law and the Rights of the Individual Employee 150

12.1 Checklist of Individual Employment Rights 150

12.2 Anti-Discrimination Legislation and Employee Rights 152

12.3 The Equality Commissions 153

12.4 Equal Pay 153

12.5 Maternity Rights Legislation 155

12.6 Other Rights to Time Off from Work 157 
12.7 Discrimination against Disabled Persons 158

12.8 Sick Pay and Medical Suspension 158

12.9 Payment to Workers When There is No Work to Do 159

12.10 The Working Time Directive 159

12.11 Transfer of Undertakings 160

12.12 The Limits of Employment Law 160

13 Fair Pay and Employee Benefits at Work 162

13.1 Factors Affecting Salary and Wage Levels 162

13.2 The Wage-Effort Bargain 164

13.3 Wage and Salary Administration Policies 164

13.4 Job Evaluation and the Design of Pay Structures 165

$\begin{array}{lll}13.5 & \text { External Pay Comparisons } & 176\end{array}$

13.6 Salary and Wage Administration 177

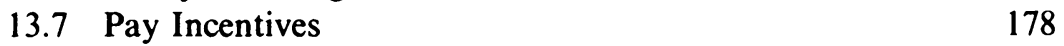

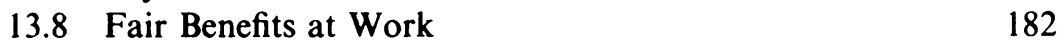

13.9 What of the Future? 182

14 Managing the Employment Relationship 183

14.1 A Corporate Perspective on Employment Relations 183

14.2 Managerial Choice of Employment Strategies 185

14.3 Perspectives on the Employment Relationship 186

14.4 Managing the Employment Relationship: The Options for Management 187

14.5 Direct or Indirect Participation? 192

14.6 Employee Relations Roles in the Workplace 192

14.7 The Lessons for Personnel Specialists on the
Management of the Employment Relationship

15 Terminating Employment 198

15.1 Dismissal: An Introduction 198

$\begin{array}{ll}15.2 \text { Defining 'Discipline' } & 199\end{array}$

15.3 Disciplinary Procedures 199

15.4 The Law on Dismissal 200

15.5 Capability or Qualifications $\quad 204$

15.6 Conduct 205

$\begin{array}{lll}15.7 \text { Redundancy } & 209\end{array}$

$\begin{array}{lll}15.8 & \text { Legal Restrictions } & 214\end{array}$

15.9 Some Other Substantial Reason $\quad 214$

$\begin{array}{ll}15.10 \text { Retirement } & 214\end{array}$

16 The Future is Not Far Away 217

16.1 What of the Future? 217

16.2 The Future: The Challenge for Personnel Management 218 
16.3 Developing Mechanisms for the More Effective Control of a Workforce

16.4 Encouraging Employee Commitment

16.5 Flexibility: The Key to the Future

16.6 The Implications for the Personnel Specialist

Answers

Further Reading 236

Index 


\section{Introduction}

This book is about the search for success in the management of people at work. Unfortunately, in the past, more attention has been given to the mismanagement of employees and the reasons for this than to the development of criteria for success in personnel management. Any attempt to generate universal prescriptions for effectiveness in this area of management is likely to be misleading. What appears to stimulate work of both high quality and quantity in one organisation may not be successful elsewhere. Nor should we assume that other nations have all the answers. Once, everything American was thought likely to be the key to industrial utopia. Then many people were excited by Japanese management techniques. Now we recognise that the search for excellence is long and difficult.

This book is not a panacea for all ills. It attempts to assist the new personnel specialist or manager to develop competence in this area. It encourages more experienced practitioners to question established techniques. On the basis of such analysis it should be possible to develop strategies and practices relevant to the circumstances of the particular organisation. Management is a lonely business; there are no guaranteed steps to effectiveness. Yet, paradoxically, no problem is unique. We hope to emphasise the complexity of good personnel management practice and the rejection and questioning, where relevant, of current employment practices.

While writing this book we have learnt the difficulty of deciding how much emphasis to give to each topic. Of necessity the results reflect our own values, experiences and interests. The further reading section at the end of the book gives limited advice for the extension of knowledge in this area of management. Experience, especially if reflected upon and shared with other practitioners, is at least as important. 